\title{
KONSERVASI SUMBER MATA AIR BAUMATA BERBASIS MASYARAKAT LOKAL
}

\author{
Meilyn Renny Pathibang1), Ni Kade Ayu Dewi Aryani' ${ }^{2)}$, Jeriels Matatula ${ }^{3)}$ \\ ${ }^{1,2,3)}$ Jurusan Kehutanan, Politeknik Pertanian Negeri Kupang \\ E-mail: ${ }^{3}$ Jerielsforestry@ gmail.com
}

\begin{abstract}
Abstrak
Provinsi Nusa Tenggara Timur merupakan salah satu provinsi dengam ketersedian air bersih dan salinitasi lingkungan yang masih minim, karena keterbatasan yang dialami dalam proses penyedian sarana dan prasarana sehingga perlu mendapat perhatian semua pihak. Sebanyak enam dari dua puluh satu kabupaten/kota di Provinsi Nusa Tenggar Timur (NTT) masih rawan atau kesulitan mendapatkan air bersih untuk kebutuhan hidup sehari-hari. Permasalahan utama yang dihadapi oleh Kelompok Masyarakat Peduli Sumber Mata Air Baumata adalah menurunnya debit air akibat maraknya penebangan liar di sekitar sumber mata air terutama di kawasan hutan bagian hulu yang merupakan daerah tangkapan air. Berbagai Tahapan atau langkah-langkah telah ditempuh guna melaksanakan solusi atas permasalahan spesifik yang dihadapi oleh Kelompok Masyarakat Peduli Sumber Mata Air Baumata. Luaran yang telah dicapai adalah masyarakat yang telah mengikuti penyuluhan tentang konservasi sumber mata air Baumata, diharapkan memilik kesadaran untuk berpartisipasi melakukan konservasi terhadap sumber mata air baumata.
\end{abstract}

Kata Kunci : Pembibitan Cendana, Pembibitan Mahoni, Sumber Mata Air

\section{PENDAHULUAN}

Indonesia merupakan negara megbiodiversity nomor tiga di dunia dengan luas $1,3 \%$ dari luas bumi, memiliki 90 jenis ekosistem khas habitat flora-fauna $10 \%$ jenis reptilia, $17 \%$ jenis burung, $25 \%$ jenis ikan, $33 \%$ jenis serangga, dan $40 \%$ dari jenis coral yang ada di seluruh dunia (Harsono, 2000). Luas hutan di Indonesia pada tahun 1950 hampir 159.000 .000 ha $(87,0 \%)$ dari total luas lahan daratan (182.700.000 hektar). Antara tahun 1950 dan 1997, hutan yang gundul 59.000.000 ha sedangkan antara 1997 dan 2015 hutan yang hilang luasannya mencapai 9.000.000 ha (Tsujino et al., 2016).

Secara keseluruhan pada periode 1950-1997 Indonesia mengalami kehilangan dan deforestasi hutan seluas 1.325.319 ha per tahun (Awang, 2006). (Badan Pusat Statistik Indonesia, 2016), saat ini luas hutan secara keseluruhan di Indonesia adalah 124.023.000 ha yang terdiri dari hutan lindung 29.917.000 ha, suaka alam dan pelestarian alam 27.399.000 ha, hutan produksi terbatas 27.687.000 ha, hutan produksi 28.897.000 ha dan hutan produksi yang dikonservasi 15.525.000 ha.

Forest Watch Indonesia mencatat, bahwa hutan asli indonesia hanya tinggal $20 \%$ atau setara dengan 130 juta hektar (Forest Watch Indonesia, 2014). Akibat kerusakan hutan mengakibatkan fungsifungsi lingkungan yang sangat mendasar untuk mendukung kehidupan manusia terabaikan, oleh karena itu memelihara lingkungan yang sehat dan seimbang berarti menjaga semua komponen lingkungan dalam kondisi yang baik (Harsono, 2000). Kehilangan arel hutan diduga dapat mengakibatkan kehilangan kekayaan hayati sebanyak 20-50\% dari semua spesies pada abad berikutnya (Forest Watch Indonesia, 2014). Manusia mampu menentukan perubahan ekologi, salah satu melalui dinamika populasi, dan susunan komunitas (King and Tschinkel, 2013).

Air merupakan kebutuhan esensi bagi manusia karena hampir $70 \%$ dari tubuh terdiri dari cairan. Selain itu, air juga berpengaruh terhadap kualitas lingkungan hidup manusia. Makin banyak air yang tersedia dengan kualitas yang baik akan meningkatkan derajat kesehatan mansyarakat dan lingkungannya (Slamet, 1994)

Provinsi Nusa Tenggara Timur merupakan salah satu provinsi dengan ketersedian air bersih dan salinitasi lingkungan yang masih minim, sebanyak enam dari dua puluh satu kabupaten/kota di Provinsi Nusa Tenggar Timur (NTT) masih rawan atau kesulitan mendapatkan air bersih untuk kebutuhan hidup sehari-hari. Enam kabupaten rawan air bersih tersut adalah Kabupaten Ende, khususnya pulau Ende, Sika, Solor, Belu Kabupaten Kupangserta Sumba Timur. Disebut sebagai daerah rawan air bersih, karena masyarakat didaerah ini tidak dapat memenuhi kebutuhan air bersih sesai dengan ketentuan yakni 30 liter/orang/hari. Mereka hanya memanfaatkn sumur gali yang debitnyaairnya sangat 
terbatas, sehingga tidak bisa memenuhi kenbutuhan air minum perhari ( Bapeda NTT, 2010).

Masyarakat yang berdomisili di Desa Baumata merupakan campuran suku di NTT, yaitu suku asli Timor, Rote, Sabu, Alor dan Flores sehingga budaya masyarakatnya sangat heterogen. Keanekaragaman budaya ini terletak pada penggunaan bahasa daerah, adat istiadat, dan corak tenun pakaiaan daerah. Pada umumnya memiliki pekerjaan utama sebagai petani dan peternak petani.

Kualifikasi pendidikan masyarakatnya adalah SLTA sebanyak 518 orang, D3 sebanyak 25 orang, S1 sebanyak 192 orang dan S2 sebanyak 15 orang (BPS NTT, 2010). Masyarakat desa di wilayah sumber mata air sudah lama menebang kayu usia muda berdiameter antara 5-10 $\mathrm{cm}$ untuk dijual kepada para kontraktor sebagai tiang penyangga bangunan.

Permasalahan utama yang dihadapi oleh Kelompok Masyarakat Peduli Sumber Mata Air Baumata adalah menurunnya debit air akibat maraknya penebangan liar di sekitar sumber mata air terutama di kawasan hutan bagian hulu yang merupakan daerah tangkapan air. Maraknya penebangan liar yang terjadi di bagian hulu mengakibatkan sebagian wilayah tangkapan air menjadi rusak. Permasalahan lain yang dihadapi adalah sebagian besar masyarakat sekitar belum menyadari akan pentingnya sanitasi sumber mata air tersebut sehingga keterlibatan masyarakat dalam memelihara sumber mata air sangat rendah. Berdasarkan berbagai permasalahan yang maka kami tim PKM dan masyrakat peduli sumber Mata Air melakukan kegiatan pengabdian pada desa Baumata.

\section{METODE KEGIATAN}

Kegitan ini dilakasanakan dengan menggunakan metode Penyuluhan dan praktek langsung dilapangan. Metode ini digunakan untuk menyampaikan materi penyuluhan dan pelatihan yang sifatnya menyenangkan bagi masyarakat. Pelaksanaan metode ini boleh dikatakan $20 \%$ untuk penyuluhan dan diskusi sementara hampir $80 \%$ itu diaplikasikan langsung dilapangan bersama masyarakat.

\section{HASIL DAN PEMBAHASAN}

Kegiatan Program Kemitraan Masyarakat (PKM) dilaksanakan selama 8 bulan, yaitu sejak Maret - Oktober 2018 bersama Kelompok Tani di RT 1 dan RT 2 Desa Baumata Barat, Kecamatan
Taebenu, Kabupaten Kupang. Kegiatan-kegiatan yang dilaksanakan selama PKM berlangsung adalah:

\section{Penyuluhan}

Penyuluhan dilaksanakan selama dua hari, yaitu tanggal 2-3 Juni dengan tema" Konservasi Sumber Mata Air Baumata". Penyuluhan dilaksanaka dua hari karena kondisi masyarakat yang menjadi sasaran penyuluhan hanya memiliki waktu luang yang singkat pada sore hari (maksimal 2 jam). Hari pertama penyuluhan tentang peranan daerah tangkapan air (kawasan hutan) terhadap keberlanjutan sumber mata air, dihadiri 35 orang yang terdiri dari masyarakat, mahasiswa dan teknisi. Hari kedua tentang pentingnya menjaga sanitasi lingkungan sekitar sumber mata air dan dihadiri 30 orang (masyarakat, mahasiswa, dan teknisi). Materi penyuluhan disiapkan oleh tim PKM bersama tim ahli Bapak Jeriels Matatula, S.Hut., M.Sc dan dipresentasikan oleh tim ahli. Kegiatan penyuluhan dapat dilihat pada Gambar 1.

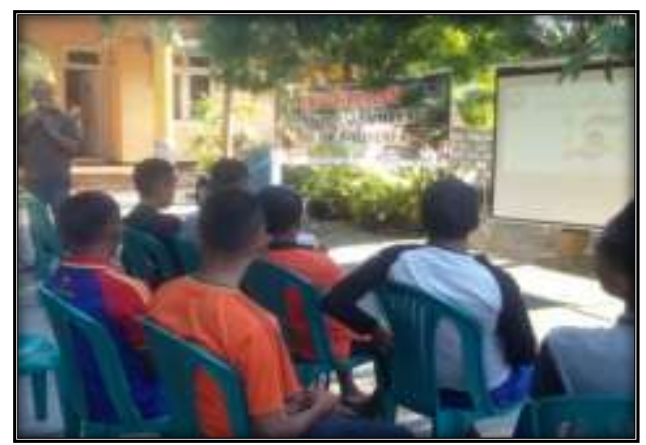

Gambar 1. Kegiatan Penyuluhan

\section{Penanaman}

Rangkaian kegiatan penanaman dilaksanakan dari tanggal 7 April sampai 30 Juni 2018 yang dimulai dari survey lokasi untuk menentukan titik penanaman (Gambar 2). Data hasil survey lokasi digunakan untuk memetakan penyebaran jenis anakan yang akan ditanam. Dari hasil pemetaan, ditentukan anakan cendana yang akan ditanam adalah 250 anakan cendana dan 100 anakan salam. Sedangkan 150 anakan mahoni yg telah disiapkan tidak ditanam sesuai arahan dari pihak Balai Konservasi Sumber Daya Alam (BKSDA) selaku pengelola kawasan hutan di sekitar sumber mata air Baumata. 150 anakan mahoni tersebut ditanam di pekarangan dan di kebun masyarakat.

Kegiatan pengabdian selanjutnya adalah pemasangan patok dan pembuatan lubang tanam sebanyak 500 lubang termasuk 150 lubang tanam di kebun dan pekarangan masyarakat (Gambar 3). Ukuran lubang tanam yang dibuat adalah $30 \mathrm{~m}$ x 30 
$\mathrm{m} x$ 30. Lubang tanam yg sudah digali, diberi pupuk bokasi sebanyak $5 \mathrm{~kg}$ per lubang (Gambar 4). Kegiatan pengisian pupuk ke dalam lubang tanam. Seminggu setelah lubang tanam diisi dengan pupuk, dilakukan penanaman 500 anakan dalam kawasan hutan dan 150 anakan di lahan masyarakat. Sisa anakan cendana, mahoni, dan salam dibagikan kepada masyarakat setempat (Gambar 4)

Kegiatan penanaman dilakukan selama dua hari, yaitu tanggal 29-30 Juni 2018. Teknologi yang ditransfer adalah teknologi irigasi tetes menggunakan botol aqua bekas. Teknologi tersebut diaplikasikan untuk mengatasi musim kemarau yang panjang. Selain itu, masyarakat diberi info tentang tanaman inang anakan cendana untuk membantu pertumbuhan cendana. Pada penanaman ini, tanaman inang yang digunakan adalah pepaya. Kegiatan penanaman ini diikuti oleh masyarakat RT 1 dan RT 2, staf BKSDA serta beberapa mahasiswa dan teknisi dari jurusan Kehutanan.

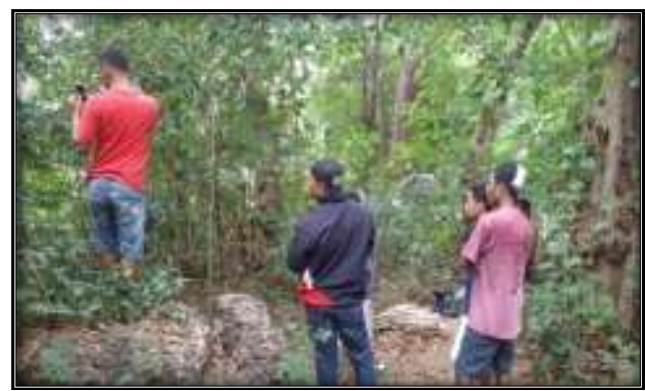

Gambar 2. Survey Lokasi
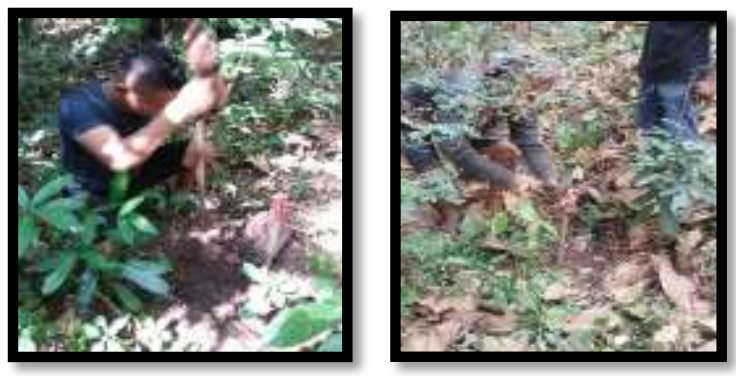

Gambar 3. Pemasangan patok dan Pengalian Lubang TanamTanam
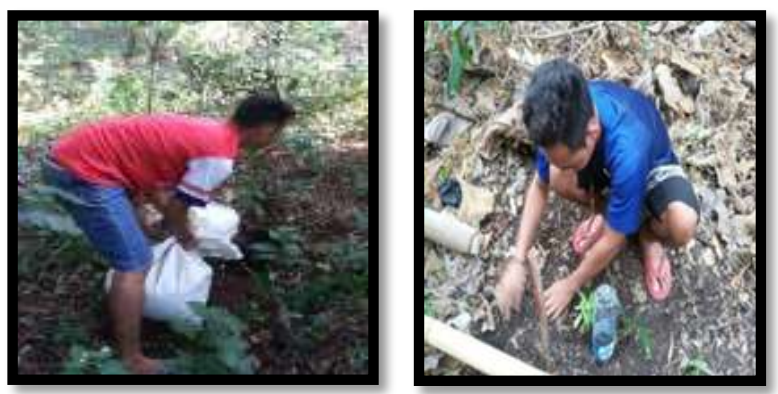

Gambar 4. Pemberian Pupuk dan Penanaman

\section{Pelatihan Pembibitan}

Pelatihan pembibitan yang dilaksanakan adalah pembibitan jenis cendana dan mahoni. Pelatihan ini dilakukan dalam dua bentuk, yaitu pelatihan dalam bentuk teori dan simulasi serta pelatihan dalam bentuk praktek langsung di lapangan. Pelatihan dalam bentuk simulasi/teori (Gambar 5).

Kegiatan awal dari sebuah persemaian adalah persiapan lahan dan pembuatan persemaian. Lahan yang digunakan adalah lahan masyarakat yang berada dekat dengan sumber air yang berasal dari sumber mata air Baumata, sesuai dengan syarat pembangunan persemaian. Persemaian yang dibangun berukuran $5 \times 7 \mathrm{~m}$. Dalam bangunan persemaian terdapat 3 bedeng tabur yang berukuran $1 \mathrm{x} 1,25 \mathrm{~m}$. IPTEK yang ditransfer ke masyarakat dalam kegiatan ini adalah syarat lokasi dan bangunan persemaian, misalnya untuk naungan digunakan waring dengan intensitas naungan $80 \%$ atau intensitas cahaya 20\% serta arah bangunan persemaian adalah ke arah Timur. Kegiatan pembangunan dan lokasi persemaian dapat dilihat pada Gambar 6.

Setelah persemaian selesai dibangun, pelatihan dilanjutkan dengan persiapan media tanam dan pengisian polybag. IPTEK yang ditansfer adalah media dan perbandingannya yang digunakan untuk mengisi polybag, yaitu top soil : bokasi : pasir $=3$ : $2: 1$ serta media yang digunakan untuk media tabur adalah semuanya pasir. Selain itu, masyarakat diajarkan teknik mengisi polybag sehingga bisa berdiri tegak serta tidak menyebabkan media menjadi padat dalam polybag. Kegiatan ini dilaksanakan dengan jumlah polybag yang diisi adalah 6000 polybag. Kegiatan ini berlangsung cukup lama (seminggu) karena kesempatan bagi masyarakat untuk mengisi polybag hanya pada sore hari setelah mereka menyelesaikan pekerjaan mereka di kebun. Kegiatan persiapan media dan pengisian polybag dapat dilihat pada Gambar 6 .

Pelatihan selanjutnya adalah perlakuan benih sebelum disemai. Perlakuan benih yang diberikan dalam pelatihan ini adalah cara menyortir benih dan cara mematahkan dormansi benih. IPTEK yang ditansfer adalah cara mematahkan dormansi benih mahoni dan benih Cendana. Khusus benih cendana, cara mematahkan dormansinya berdasarkan hasil penelitian Tim Ahli pada tahun 2004. Perlakuan tersebut adalah melakukan perendaman benih dalam air dingin selama 12 jam kemudian dianginanginkan selama 12 jam (Gambar 7) dan dilakukan selama 3 hari berturut-turut. 
Kegiatan pelatihan penyemaian benih dilaksanakan pada tanggal 28 Juni 2018 (Gambar 7). Teknik penyemaian yang diberikan dalam pelatihan ini ada dua yaitu teknik menyemaikan benih secara langsung dalam 6000 ribu polybag (3000 polybag untuk cendana dan 3000 polybag untuk mahoni) dan teknik menyemaikan benih pada bedeng tabur berukuran $1 \mathrm{~m} \times 1.25 \mathrm{~m}$. Penyemaian pada bedeng tabur dipersiapkan untuk menyulam benih yang gagal tumbuh pada polybag.

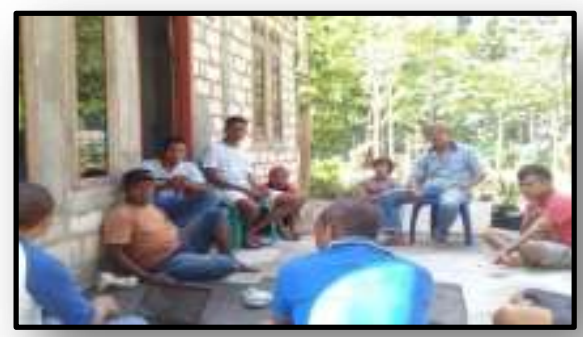

Gambar 5. Pelatihan/Simulasi Pembibitan Cendana dan Mahoni.
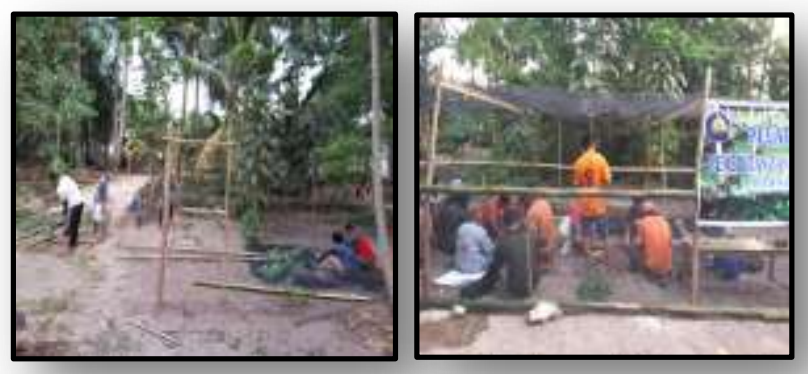

Gambar 6. Pembuatan Tempat Persemaian dan Pengisian Polybag.
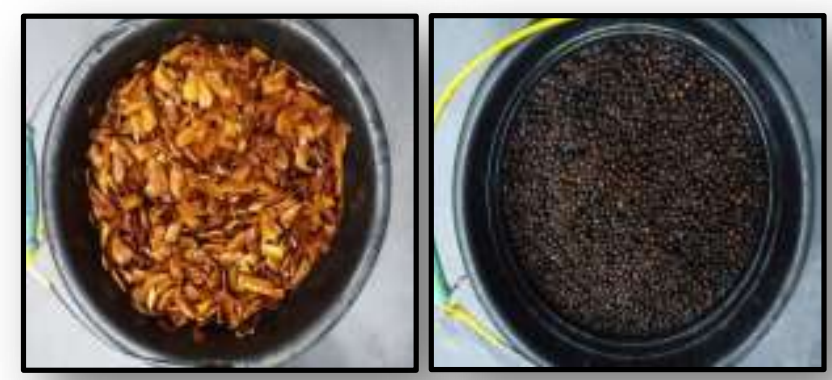

Gambar 7. Perlakuan terhadap Benih Mahoni dan Cendana
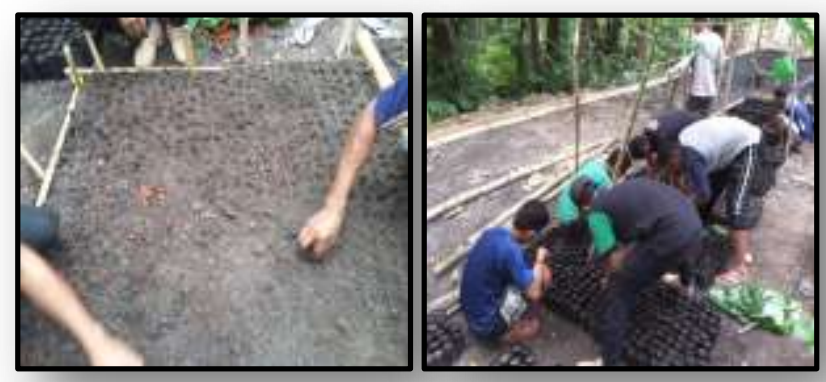

Gambar 8. Penyemayan Benih Mahoni dan Cendana

\section{Pemeliharaan}

Kegiatan pemeliharaan yang dilakukan untuk anakan yang telah ditanam adalah penyiraman dan pengisian air pada botol irigasi yang sudah kosong. Pemeliharaan juga dilakukan di persemaian. Pemeliharaan yang dilakukan adalah penyiraman setiap pagi dan sore yang dilakukan oleh masyarakat (Gambar 9).
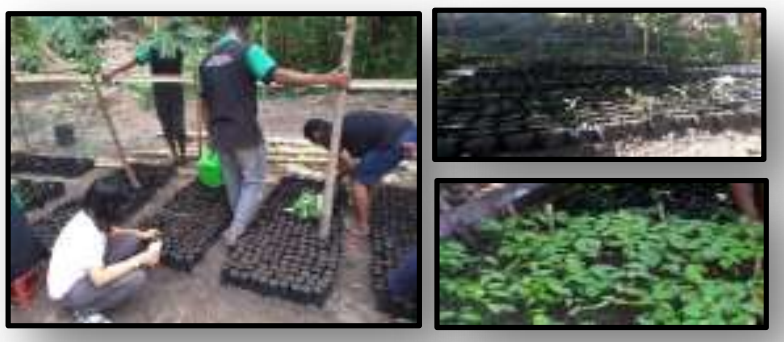

Gambar 9. Kegiatan Pemeiliharaan

\section{Pembersihan, Pengecatan dan Pemagaran Bak Penampung.}

Selain kegiatan penanaman dan pembibitan, Tim PKM bersama masyarakat juga melakukan pembersihan, pengecatan dan pemagaran bak penampung (Gambar 10). Kegiatan tersebut dikerjakan oleh masyarakat bersama Tim PKM.

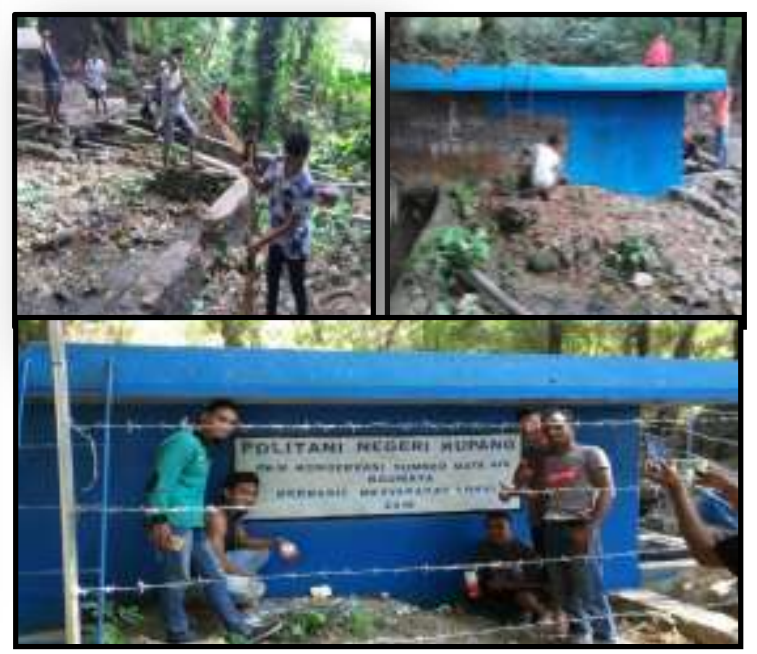

Gambar10. Pembersihan, Pengecatan dan Pemagaran Bak Penampung.

\section{Monitoring dan Evaluasi}

Setelah semua kegiatan selesai dilaksanakan, setiap minggu tim PKM melakukan monitoring dan evaluasi. Terhitung sejak selesai penanaman di kawasan, diluar jadwal kegiatan PKM yang lain, monitoring dilakukan oleh tim IbM sampai kondisi anakan di kawasan sudah bisa bertahan tanpa penyiraman (musim hujan) dan anakan di persemaian layak tanam dan layak jual (tinggi minimal $30 \mathrm{~cm}$ ). Hasil monitoring dan evaluasi tim 
PKM menunjukkan bahwa dari tiga ribu polybag yang telah disemai cendana ada 2.448 benih yang berhasil tumbuh sedangkan untuk mahoni, ada 2.700 benih yang sudah tumbuh. Benih yang tidak tumbuh disulam menggunakan semai dari bedeng tabur. Seluruh rangkaian kegiatan PKM telah dimonev oleh pihak DRPM sebagai penyandang dana (Gambar 11).

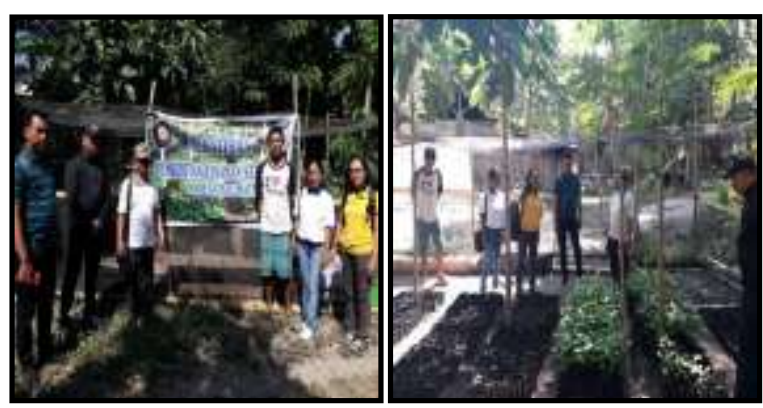

Gambar 11. Monev Eksternal dari DRPM

\section{KESIMPULAN}

\section{Kesimpulan}

1. Luaran yang diperoleh dari kegiatan penyuluhan adalah meningkatnya pengetahuan dan pemahaman masyarakat mengenai konservasi sumber mata air.

2. Luaran yang telah dicapai dari kegiatan pelatihan pembibitan adalah 6 ribu polybag yang telah disemai benih cendana dan mahoni dan dari presentasi tumbuhnya yaitu $85 \%$ dan $90 \%$, kegiatan pelatihan pembibitan dinyatakan berhasil

3. Luaran yang telah dicapai dari kegiatan rehabilitasi adalah 500 anakan cendana, mahoni, dan salam yang telah ditanam di kawasan tangkapan air dan lahan masyarakat.

4. Kegiatan konservasi lain yang dilakukan tim PKM adalah pembersihan di sekitar bak penampung serta pengecatan dan pemagaran bak penampung.

\section{Saran}

Perlu pendampingan lanjut bagi masyarakat untuk melakukan konservasi di sekitar sumber mata air.

\section{REFERENSI}

Awang S. A. (2006) Sosiologi Pengetahuan Deforestasi Konstruksi Sosial dan Perlawanan. Yokyakarta.Debut Press.

Badan Pusat Statistik Indonesia (2016) Kehutanan Indonesia. Badaan Pusat Statistik Indonesia.

Barus T. (2004) Pengantr Limnologi Studi Tentang Ekosistem Sungai Dan Danau. Medan.

BPS-NTT. 2004. Buku saku statistik NTT. Katalog BPS. 1403.53. Biro Pustaka Statistik Propinsi Nusa Tenggara Timur. 157 hal.

Forest Watch Indonesia (2014) Potret Keadaan Hutan Indonesia. 1st edn. Bogor.

Harsono (2000) Strategi dan Kebijakkan Konservasi di Hutan Produksi, Makala Utama Seminar Nasional Fakultas Kehutanan. Yogyakarta: Universitas Gajha Mada 26-27 Mei 2000.

Hutabarat. 2006. Model Forest : Alternatif Pengelolaan Hutan di NTT. Sosialisasi HasilHasil Litbang Kehutanan kepada Pengguna. Balai Litbang Kehutanan Bali dan Nusa Tenggara. Kupang, 14 Februari 2006.

Indriyanto (2010) Ekologi Hutan. Edited by Indriyanto. Lampung. PT. Bumi Aksara.

King, J. R. dan Tschinkel, W. R. (2013) Fire ants are not drivers of biodiversity change: Ecological Entomology, 8(6), pp.543-545.

Tsujino, R., Yumoto, T., Kitamura, S., Djamaluddin, I. and Darnaedi, D. (2016) History of forest loss and degradation in Indonesia', Land Use Policy. Elsevier Ltd, 57, pp. 335-1016.

Wirakusumah, S. (2003) Dasar-Dasar Ekologi Bagi Populasi Dan Komunitas. 1st edn. Edited by S. Sriwibawa. Jakarta. 